\title{
Allergic Contact Dermatitis with Diffuse Erythematous Reaction from Diisopropanolamine in a Compress
}

\author{
Tomoko Rind Naoki Oiso Ayaka Hirao Akira Kawada \\ Department of Dermatology, Kinki University School of Medicine, Osakasayama, \\ Japan
}

\section{Key Words}

Allergic contact dermatitis - Diisopropanolamine - Compress - Diffuse erythematic reaction

\begin{abstract}
Compresses containing a nonsteroidal antiinflammatory drug (NSAID) are commonly used in Japan. However, this treatment may induce both allergic and photoallergic contact dermatitis from the NSAIDs and their ingredients. Here, we describe a case of allergic contact dermatitis with diffuse erythematous reaction due to diisopropanolamine in the applied compress. The absorption of diisopropanolamine might have been enhanced by the occlusive condition.
\end{abstract}

\section{Introduction}

Compresses containing a nonsteroidal antiinflammatory drug (NSAID) are frequently used in Japan. However, the style of the application may induce both allergic and photoallergic contact dermatitis from the NSAIDs and their ingredients [1-3]. We describe a case of allergic contact dermatitis with diffuse erythematous reaction caused by allergic sensitivity to a component, diisopropanolamine, of a compress used by the patient.

\section{Case Report}

An 87-year-old Japanese man with dementia presented with a pruritic eruption following the use of compresses for lumbago. The patient had used the same compresses for three weeks. During the last ten days of use, pruritic eruptions appeared on the bilateral lower back and upper buttock where the compresses were being applied. Then, diffuse erythema developed on the trunk and extremities. Physical examination revealed rectangular-shaped, pruritic exudative erythematous macular lesions on 


\begin{tabular}{c|l|l|l} 
Case Reports $h$ & Case Rep Dermatol 2010;2:50-54 & Published online: April 23, 2010 & $\begin{array}{l}\text { @ 2010 S. Karger AG, Basel } \\
\text { ISSN 1662-6567 } \\
\text { Wwww.karger.com/cde }\end{array}$ \\
\hline Dol: $\underline{10.1159 / 000313430}$ & & & \\
\hline
\end{tabular}

the bilateral lower back and upper buttock and diffuse erythema on the chest, abdomen, back and extremities (fig. 1). The dermatitis was treated with topical steroids.

A patch test (International Contact Dermatitis Research Group criteria; Finn Chambers ${ }^{\circledR}$ on Scanpor ${ }^{\circledR}$ tape, Epitest Ltd., Tuusula, Finland) was performed with the compress' ingredients and the Japanese baseline series. The manufacturer provided the ingredients. The positive reactions at both 2 and 4 days after application were to diisopropanolamine $1 \%$ pet., fragrance mix $8 \%$ pet. (brial allergen $\mathrm{GmbH}$, Greven, Germany), and mercuric chloride $0.05 \%$ aq. (Torii Pharmaceutical Co., Ltd., Tokyo, Japan) (+ on D2 and D4) (ig. 2).

\section{Discussion}

The patient showed allergic sensitivity to diisopropanolamine in the compresses he had used. We believe that sensitization occurred while using the compresses.

Diisopropanolamine has a relatively low sensitization potential. It is used in emulsifying agents for cosmetic lotions, neutralizers in cosmetics, and bath preparations [1]. Until now, eight cases of allergic contact dermatitis from diisopropanolamine, including the present case, have been described (table 1) [1-6]. Notably, five of the eight cases were sensitized from using the compress [1-3]. The absorption of diisopropanolamine may have been enhanced by the occlusive condition.

We previously reported a case of diffuse erythematic reaction after using compresses [2]. In the previous case, three concomitant sensitizations to diisopropanolamine, felbinac, and crotamiton supposedly caused a diffuse erythematic reaction [2]. In the present case, a single sensitization to diisopropanolamine was associated with a diffuse erythema.

Thus, similar phenomena of allergic contact dermatitis with diffuse erythematous reaction may be caused by allergic sensitivity to a different component or different combinations of ingredients in the topical medicament. Patch testing with full ingredients from the manufacturer is essential for detecting the sensitized allergens in each case. 
Table 1. Cases of allergic contact dermatitis due to diisopropanolamine

\begin{tabular}{|c|c|c|c|c|}
\hline Case & $\begin{array}{l}\text { Age/ } \\
\text { sex }\end{array}$ & Clinical feature & Allergen(s) & $\begin{array}{l}\text { Products used by } \\
\text { the patient }\end{array}$ \\
\hline Present case & $87 / \mathrm{M}$ & $\begin{array}{l}\text { rectangular-shaped, pruritic } \\
\text { exudative erythematous macular } \\
\text { lesions with diffuse erythema }\end{array}$ & diisopropanolamine & $\begin{array}{l}\text { compress } \\
\text { containing } \\
\text { felbinac }\end{array}$ \\
\hline $\begin{array}{l}\text { Umebayashi, } \\
2005 \text { [1], 1st case }\end{array}$ & $78 / \mathrm{F}$ & pruritic erythematous erythema & diisopropanolamine & $\begin{array}{l}\text { compress } \\
\text { containing } \\
\text { felbinac }\end{array}$ \\
\hline $\begin{array}{l}\text { Umebayashi, } \\
2005 \text { [1], 2nd case }\end{array}$ & $76 / \mathrm{F}$ & erythema and papules & diisopropanolamine & $\begin{array}{l}\text { compress } \\
\text { containing } \\
\text { felbinac }\end{array}$ \\
\hline $\begin{array}{l}\text { Oiso et al., } \\
2003[2]\end{array}$ & $65 / \mathrm{M}$ & $\begin{array}{l}\text { rectangular-shaped, pruritic } \\
\text { exudative erythematous macular } \\
\text { lesions with diffuse erythema }\end{array}$ & $\begin{array}{l}\text { diisopropanolamine, felbinac, and } \\
\text { crotamiton }\end{array}$ & $\begin{array}{l}\text { compress } \\
\text { containing } \\
\text { felbinac }\end{array}$ \\
\hline $\begin{array}{l}\text { Umebayashi, } \\
2000[3]\end{array}$ & $45 / \mathrm{M}$ & $\begin{array}{l}\text { rectangular-shaped, pruritic } \\
\text { exudative erythema }\end{array}$ & diisopropanolamine & $\begin{array}{l}\text { compress } \\
\text { containing } \\
\text { felbinac }\end{array}$ \\
\hline $\begin{array}{l}\text { Hosokawa et al., } \\
1993[4]\end{array}$ & $31 / \mathrm{F}$ & pruritic exudative erythema & $\begin{array}{l}\text { ketoprofen and oxybenzone as } \\
\text { photoallergens, and } \\
\text { diisopropanolamine and } \\
\text { polyoxyethyleneoreil eter as allergens }\end{array}$ & a topical lotion \\
\hline $\begin{array}{l}\text { Fujimoto et al., } \\
1989 \text { [5] }\end{array}$ & $60 / \mathrm{M}$ & $\begin{array}{l}\text { severely pruritic diffuse and } \\
\text { edematous erythema }\end{array}$ & diisopropanolamine & $\begin{array}{l}\text { a topical } \\
\text { ointment }\end{array}$ \\
\hline Cronin, 1980 [6] & $? / \mathrm{F}$ & $?$ & diisopropanolamine & a blushing gel \\
\hline
\end{tabular}


Fig. 1. Rectangular-shaped erythema on the bilateral lower back and the buttock and a diffuse erythema on the trunk and extremities.

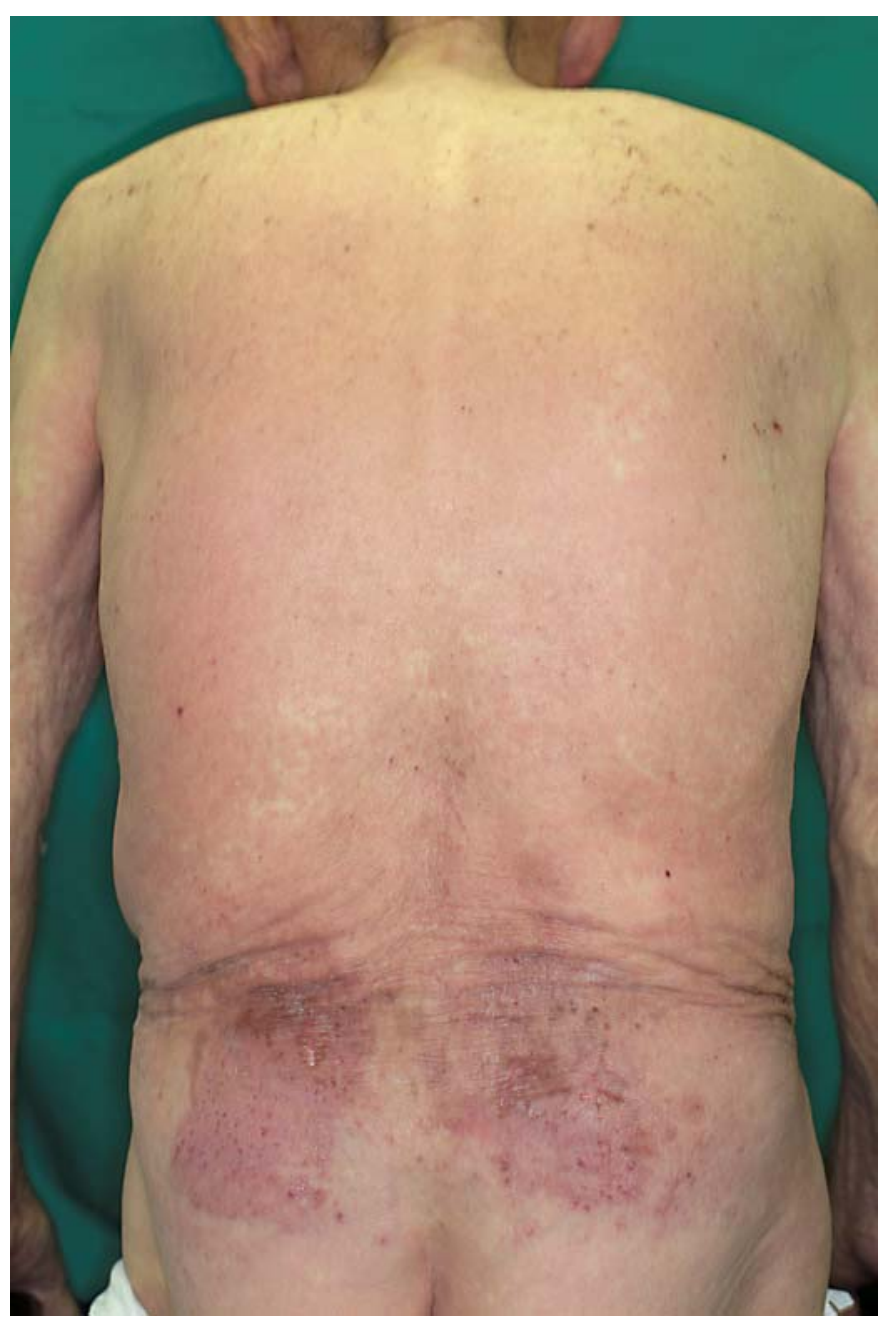

Fig. 2. Patch testing showed positive reaction to diisopropanolamine on day 4 .

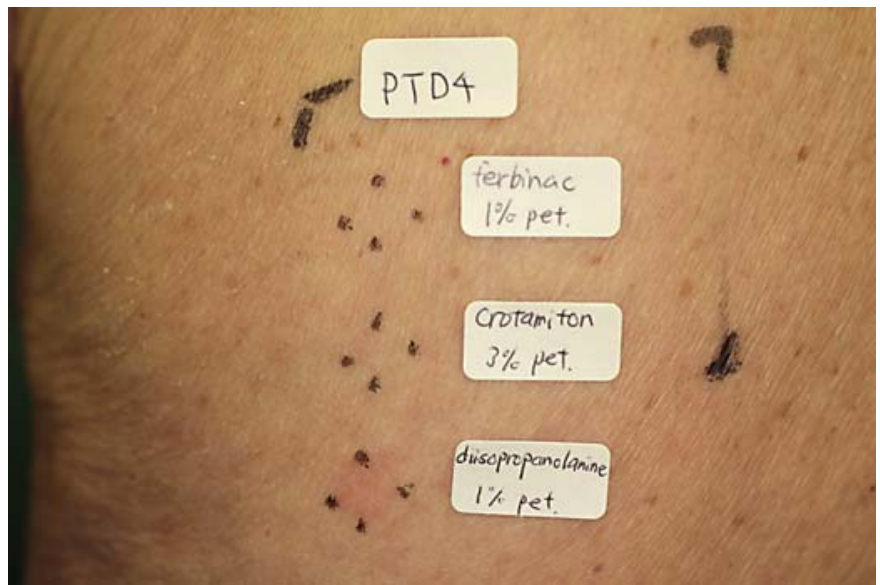




\section{References}

1 Umebayashi Y: Two cases of contact dermatitis due to diisopropanolamine. J Dermatol 2005;32:145-146.

2 Oiso N, Fukai K, Ishii M: Triple allergic contact sensitivities due to ferbinac, crotamiton and diisopropanolamine. Contact Dermatitis 2003;49:261-263.

3 Umebayashi Y: Contact dermatitis due to diisopropanolamine (in Japanese). Rinsho Derma (Tokyo) 2000;42:526-527.

4 Hosokawa K, Mitsuya K, Nishijima S, Horio T, Asada Y: Photocontact dermatitis from a non-steroidal anti-inflammatory drug (Sector Lotion ${ }^{\circledR}$ ) (in Japanese). Skin Research 1993;35:26-32.

-5 Fujimoto K, Hashimoto S, Kozuka T, Yoshikawa K: Contact dermatitis due to diisopropanolamine. Contact Dermatitis 1989;21:56.

6 Cronin E: Ibid. ref. [5], p. 149. 